\title{
Species composition of introduced and natural minnow populations of the Phoxinus cryptic complex in the westernmost part of the Po River Basin (north Italy)
}

\author{
Vanessa De Santis (D) Giovanni B. Delmastro - Isabella Vanetti • \\ J. Robert Britton · Serena Zaccara
}

Received: 18 May 2020/Accepted: 28 October 2020/Published online: 13 November 2020

(C) The Author(s) 2020

\begin{abstract}
Invasive alien species are a major driver of biodiversity loss, with their impacts potentially more intense when complexes of cryptic species are involved. In freshwaters, the anthropogenic manipulation of fish communities has resulted in altered fish communities, and in Europe has increased the complexity of Phoxinus species assemblages. Here, we investigated the Phoxinus communities of the westernmost part of the Po river basin, where adjacent freshwater ecosystems (Alpine high-altitude lakes and lowland streams) are representative of different management strategies (i.e. manipulated fish communities
\end{abstract}

Electronic supplementary material The online version of this article (https://doi.org/10.1007/s10530-020-02406-2) contains supplementary material, which is available to authorized users.

V. De Santis $(\bowtie) \cdot$ I. Vanetti · S. Zaccara

Department of Theoretical and Applied Sciences, Insubria

University, Via Dunant 3, 21100 Varese,

VA, Italy

e-mail: v.desantis1@uninsubria.it

G. B. Delmastro

Ichthyology Section, Carmagnola Natural History

Museum, Cascina Vigna, Via S. Francesco di Sales, 188,

10022 Carmagnola, TO, Italy

\section{J. R. Britton}

Institute of Aquatic Sciences, Department of Life and

Environmental Sciences, Faculty of Science and

Technology, Bournemouth University, Fern Barrow,

Poole, Dorset BH12 5BB, UK via stocking in Alpine lakes vs. natural populations in streams). We tested the genetic composition of the cryptic Phoxinus populations inhabiting these waters, as the species are morphologically indistinct. Sequences of the mitochondrial cytochrome oxidase I (COI) were obtained from 239 specimens, with the results indicating that 17 Alpine high-altitude lakes are now populated by a complex of Phoxinus species, comprising $P$. septimaniae (native to the Mediterranean area of France), P. csikii (native to the Central Balkans) and $P$. lumaireul (native to the North Adriatic Sea basins). Their introduction resulted from their use as angling live baits. Minnow populations in lowland streams were primarily comprised of native $P$. lumaireul, with only a single $P$. csikii specimen detected. While nuclear sequences of the recombination activating gene 1 (RAG1) marker were not useful for tracking the presence of alien alleles in these stream populations, the COI data emphasised the importance of using molecular tools to investigate cryptic species complexes that have been modified by anthropogenic activities.

Keywords Cryptic invasion - Alpine lakes ·

Phoxinus lumaireul · Multiple introduction · European minnows $\cdot$ Live baits 


\section{Introduction}

Invasive alien species are an important driver of biodiversity loss in aquatic ecosystems (Milardi et al. 2018) and can result in serious economic impacts (Gallardo et al. 2016). Freshwater fish communities can be highly impacted by alien species, with invasions facilitated by the high connectivity of river habitats that enables rapid dispersal (Hermoso et al. 2011). In the Mediterranean region, alien fish account for more than a quarter of the total number of fish species present (Leprieur et al. 2008). For example, in Italy there are 41 established alien fish species present, compared with 48 native species (Nocita et al. 2017); in some rivers, such as the downstream areas of the River Po, the native fish community has largely been substituted by alien fish species (Lanzoni et al. 2018).

When a new alien fish introduction has occurred, its effective management requires it to be detected early, ideally before the species establishes, followed by a commensurate intervention, such as eradication for a high risk species (Vander Zanden et al. 2010; Britton et al. 2011). Early detection usually results in fewer resources being required for eradication as the alien species is still of low abundance and spatially constrained (Britton et al. 2011). However, this early detection can be hindered by the unresolved taxonomic status of species, or by the presence of cryptic species (Bickford et al. 2007). This increases the likelihood of a 'hidden' invasion, i.e. one that goes unnoticed until the invader has established and dispersed, and so has achieved a relatively wide distribution before being detected (Morais and Reichard 2018). Indeed, while cryptic alien species are widespread across different taxa (Pfenninger and Schwenk2007; Adams et al. 2014), many are assumed to remain undetected within communities of native species (Morais and Reichard 2018). Consequently, their detection is increasingly reliant on the application of molecular tools (e.g. Smith et al. 2012; Uchii et al. 2016).

An example of a cryptic species complex whose species composition and distributions remain subject to considerable knowledge gaps is that of the Eurasian minnows of the genus Phoxinus Rafinesque 1820. A group of cyprinoid fishes (Mayden and Chen 2010), the Phoxinus genus is characterized by a wide distribution range (basins of Atlantic, North and Baltic Seas, the Arctic and the northern Pacific Ocean), with its species able to populate a wide range of habitats, from large lowland rivers and lakes to the cold, welloxygenated waters of fast-flowing mountain streams (Kottelat and Freyhof 2007). As minnow populations only show subtle morphological differences and phenotypic plastic responses to different habitat typologies (Ramler et al. 2016), only one European species was initially described, $P$. phoxinus (Kottelat and Freyhof 2007). In the last decade, however, morphological and molecular studies have suggested that the Phoxinus genus comprises of at least 19 valid species (Eschmeyer et al. 2020). Within these species, the Italian minnow $P$. lumaireul Schinz 1840 has been re-validated as a species (Kottelat 2007) and it is endemic to basins of the north Adriatic Sea $(P$. lumaireul sensu stricto i.e. clade 1a; Palandačić et al. 2017).

The distribution of European minnows has been altered by introduction practices that have occurred via their use as angling live baits or through being contaminants of stocks of salmonids being used to enhance angling, especially in high-altitude or highlatitude lakes (e.g. Museth et al. 2007; Miró and Ventura 2015). Natural hybridization zones can further increase the complexity in defining the actual distribution ranges of these species (Palandačić et al. 2017; Corral-Lou et al. 2019), despite the relevance of this information for planning suitable strategies for conserving the native lineages and managing the distributions of alien ones. As a result of these processes, there is now minimal information available on the composition of the Phoxinus communities in many areas in southern Europe, including in the River Po basin. Correspondingly, in this study, we investigated how anthropogenic activities have impacted the cryptic species complex of the Phoxinus genus in the adjacent freshwater ecosystems of Alpine high-altitude lakes and lowland streams, focusing on the westernmost area of the River Po basin. In this area, the high-altitude lakes are regarded as being naturally fishless (Tiberti et al. 2014) and the lowland streams are recognised as the natural distribution range of $P$. lumaireul sensu stricto (i.e. locus typicus; Schinz 1840), with no known minnow stockings. To determine the species present within this cryptic species complex, we applied molecular (mtDNA and nDNA) tools, an approach that also enabled assessment of the genetic integrity of the native populations in the 
lowland streams, an aspect important for their conservation.

\section{Materials and methods}

Sampling

The sampling of the Phoxinus communities covered the westernmost part of the Po River basin in the Piedmont region of Italy. Among 30 Alpine lakes visited in the sampling period, introduced minnows were detected in 17 lakes that were in the Western Alps at 1500-2500 m.a.s.l. (Figure 1; Online resources Table ESM 1). Of these 17 lakes, four were ponds with depths below $3 \mathrm{~m}$ (CFO, ISC, RES, ORG), with the others all being typical Alpine lakes with maximum depths between 3 and $5 \mathrm{~m}$, and of sizes of approximately 0.5 (ISC, RES and ORG) to 158 ha (CER). Most were of natural, glacial and karstic origin, but three (CER, TER and CHI) were manmade. Most had a perennial outflow, although the outflow was intermittent for five lakes (VIS, ROB, TER, ANN, RES). The common feature of these lakes was that they are naturally fishless (Giussani 1997) and their fish community is artificial, reflecting the local practice of species introductions for angling. Indeed, fish releases for angling are a widespread practice in the Alps (Jersabek et al. 2001), as well as in other high-altitude lakes, such as in the Pyrenees in Europe (Miró and Ventura 2015). In the lakes, we also detected the presence of other fish species, mainly salmonids (Online resources Table ESM 2).

In the westernmost lowland streams which were all tributaries of the Po River, the fish assemblages included Phoxinus spp., with other species present being typical of those inhabiting the hyporhitral 'Grayling zone' and the epipotamal 'Barbel zone'. Alien fishes such as Gobio gobio, Salmo trutta and its hybrids with the native $S$. marmoratus, Oncorhynchus mykiss and Salvelinus fontinalis were present across the sampled sites (i.e. PEL, VAR and PES) (Table ESM 2).

Between June 2016 and 2019, a total of 157 and 82 Phoxinus specimens were collected from the 17 Alpine high-altitude lakes and the four lowland streams respectively (Table ESM 1). This sampling was conducted using electric fishing in lowland streams, and by line fishing and hand nets in the

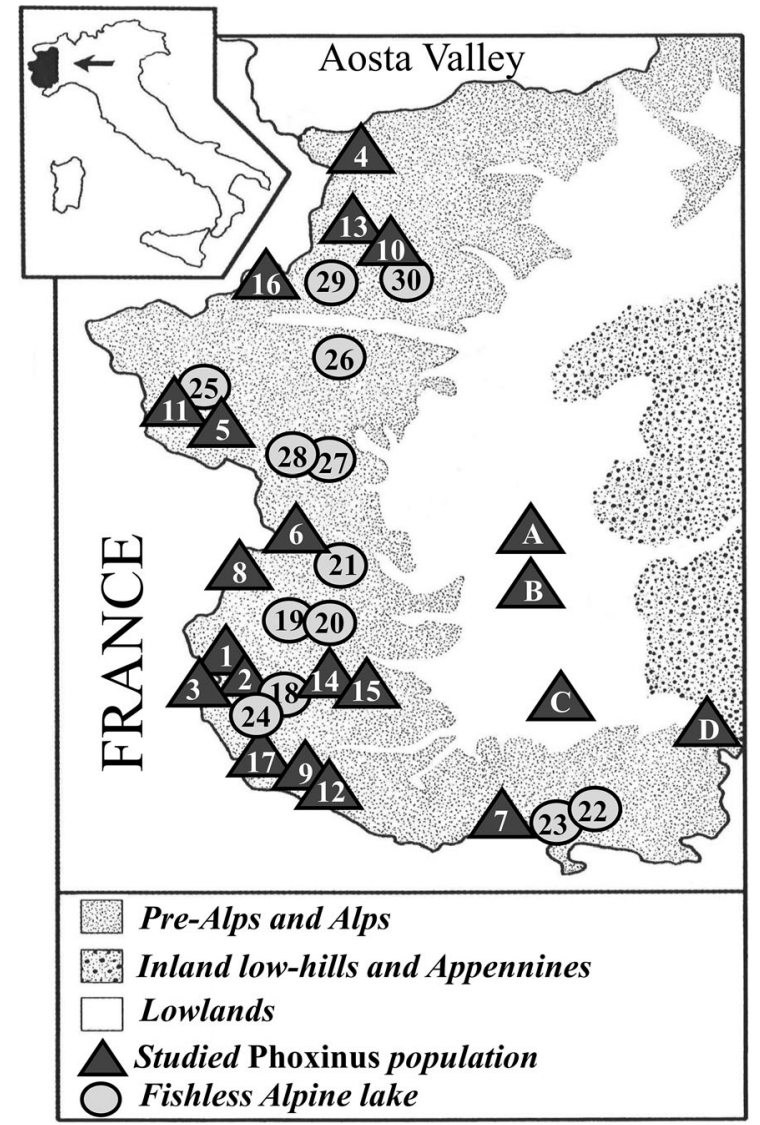

Fig. 1 Distribution map of the four lowland streams (letters from A to D) and 30 high altitude Alpine lakes (numbers from 1 to 30) visited in summers 2017-2019. Triangles indicate where Phoxinus specimen were found whilst circles indicate Alpine lakes where fish were absent (i.e. fishless). Streams: AConfluence between Pellice and Po (PEL); B-Varaita (VAR); C-Pesio (PES); D_Valla (VAL); Lakes: 1-Visaisa (VIS); 2-Roburent (ROB); 3-Maddalena (MAD); 4-Ceresole (CER); 5-Nero-Cesana (CES); 6-Fiorenza (FIO); 7-Terrasole (TER); 8-Nero-Pontechianale (CHI); 9-S. Anna (ANN); 10-Viana (VIA); 11-Clot Foiron (CFO); 12-Orgials (ORG); 13-Afframont (AFF); 14-Nero-Canosio (CAN); 15-Resile (RES); 16-Arpon (ARP); 17-Ischiator; 18Meja; 19-Bagnour; 20-Secco; 21-Luset; 22-Biecai; 23Rataira; 24-Ancoccia; 25-Clot Foiron A; 26-Balma; 27Cialancia; 28-Drajo; 29-Falin; 30-Veilet. See Online resources Table ESM 1 for further details on sampling sites where minnows were collected (i.e. altitude, geographic coordinates, number of fish analysed at both the mtDNA and nDNA)

lakes. Following their capture, all fish were anesthetized (MS-222) and a biopsy of the pelvic fin taken and preserved in ethanol (98\%). The fish were then released back to their site of capture. 
Molecular analyses

Total genomic DNA was extracted from all individuals using the salting out method based on a proteinase $\mathrm{K}$ digestion, followed by sodium chloride extraction and ethanol precipitation (Aljanabi and Martinez 1997). A fragment (635 bp) of the mitochondrial cytochrome oxidase subunit I (COI) locus was amplified from all the specimens, whilst in the lowland populations a fragment $(852 \mathrm{bp})$ of the nuclear recombination activating gene 1 (RAG1) was also amplified. Primer pairs used for each locus are available in Palandačić et al. (2017).

The PCR assays were performed using a Multiplex PCR kit (Qiagen) in $10 \mu \mathrm{l}$ reaction volume that contained approximately $10 \mathrm{ng}$ of template DNA and $0.25 \mu \mathrm{M}$ of each primers pair. For the COI locus, thermal cycling was performed as follows: denaturation of $15 \mathrm{~min}$ at $95^{\circ} \mathrm{C}$, followed by 35 cycles at $94{ }^{\circ} \mathrm{C}$ for $30 \mathrm{~s}, 55^{\circ} \mathrm{C}$ for $30 \mathrm{~s}$, and the extension step at $72{ }^{\circ} \mathrm{C}$ for $45 \mathrm{~s}$; the final elongation was at $72{ }^{\circ} \mathrm{C}$ for $10 \mathrm{~min}$. Thermal cycling conditions for RAG1 gene followed those of Palandačić et al. (2017). PCR products were purified using ExoSAP-IT ${ }^{\mathrm{TM}}$ (USB, Cleveland, USA) and directly sequenced by MACROGEN Inc (Amsterdam, The Netherlands; http://www. macrogen.org) using a 3730XL DNA Sequencer. All haplotypes generated in this study were deposited in the GenBank database (COI: MK984796-MK984822 and MT385939-MT385940; RAG1: MT410529MT410545).

Phylogenetic data analyses

All the COI and RAG1 sequences obtained were automatically aligned, and then visually checked and adjusted. Identical COI sequences were collapsed into haplotypes in order to facilitate the computational processes and reduce redundancy. For the nuclear RAG1 dataset, the haplotype phases were solved using the PHASE algorithm available in DnaSP v 6 (Rozas et al. 2017). The phylogenetic analyses were exclusively performed on the COI mtDNA, as the RAG1 nDNA fragment had a low signal that could not cluster supported phylogenetic clades (Palandačić et al. 2017; Corral-Lou et al. 2019). The COI dataset was enlarged with 191 evolutionary related sequences (Online resources Table ESM 3), with trees rooted on $P$. phoxinus (MF407769) sensu Palandačić et al. (2017).
Phylogenetic tree reconstructions were performed using neighbour joining (NJ), maximum likelihood (ML) and Bayesian inference (BI), through PAUP v 4.0 b10 (Swofford 2002), GARLI v 2.0 (Bazinet et al. 2014) and MrBayes v 3.1.2 (Ronquist et al. 2012) software respectively. The best evolutionary model, identified under the Akaike's information criterion (AIC), was GTR. Statistical support for the NJ and ML phylogenetic tree nodes was estimated as bootstrap probability (btp) values over 1000 replicates and then mapped onto the respective tree with PAUP software (Swofford 2002). Congruence in phylogenetic structure for the BI was performed using four independent Markov Montecarlo Coupled Chain (MCMC) runs of $10^{6}$ generations each to estimate the posterior probability (pp) distribution. Topologies were sampled every 100 generations, and the majority-rule consensus tree was estimated after discarding the first $25 \%$ of generations. COI mtDNA uncorrected p-distances were also estimated.

On both the mitochondrial and nuclear datasets, Minimum Spanning Networks (MSNs) were built on haplotypes through a statistical parsimony criterion as available in PopART v1.7 software (Leigh and Bryant 2015). Mitochondrial MSN was built on the sequences produced in the study, while the nuclear data set has been enriched with 32 unphased sequences retrieved from GenBank that belonged to the minnow species detected at the COI locus (Online resource Table ESM 4). For each sampling site and marker, genetic variability indices were also estimated.

\section{Results}

mtDNA phylogeny and MSN

A total of 52 haplotypes were identified in the $635 \mathrm{bp}$ length multiple COI alignment that was obtained from the 239 analysed minnows plus the 191 sequences retrieved from GenBank (Online resources Table ESM 5). There were 70 variable nucleotide positions detected, 16 of which were singletons and 54 were parsimony informative sites. Among the sequences produced in this study, 26 haplotypes were recorded of which 17 were detected for the first time (Fig. 2; Online resources Table ESM 5). The NJ, ML and BI phylogenetic analyses resulted in well-resolved and congruent trees $(\mathrm{NJ}$ btp $=100 ;$ ML btp $>76 ; \mathrm{pp}>$ 


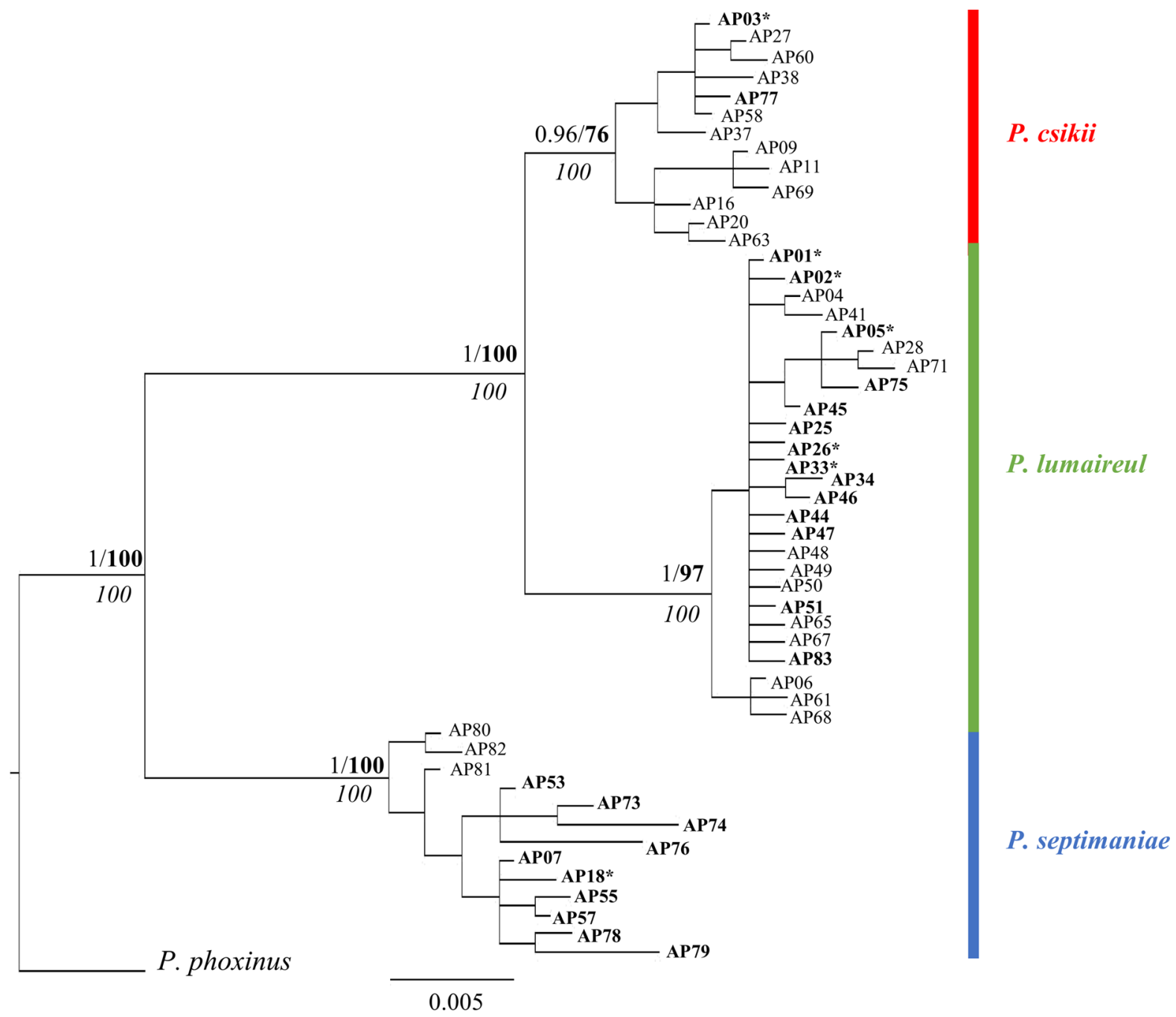

Fig. 2 Bayesian phylogenetic tree of the 52 haplotypes obtained from the multiple alignment of the 239 COI mtDNA 635 bp length sequences produced in this study enriched with 191 evolutionary related sequences retrieved from GenBank (Online resource Table ESM 3). Haplotype labels are reported beside each branch where bold labels indicate haplotypes found

0.96) in which three clusters grouped independently (Fig. 2); 14 haplotypes were identified as the endemic minnow ( $P$. lumaireul sensu stricto; clade $1 \mathrm{a}$ in Palandačić et al. 2017), 10 as Phoxinus septimaniae Kottelat 2007 (clade 12 in Palandačić et al. 2017) and two as Phoxinus csikii Hankó 1992 (clade 5a in Palandačić et al. 2017). Uncorrected p-distance values between the Phoxinus lineages ranged between 2.5 and $6.1 \%$, with the closest distance between $P$. lumaireul and P. csikii, and the largest between $P$. lumaireul and P. septimaniae (Fig. 2). in the study and asterisks where haplotypes corresponded to sequences already present in GenBank. Clades attribution follows Palandačić et al. (2017). NJ and ML bootstrap (below branches in cursive and above branches in bold respectively) and BI posterior probability (above branches) values are given next to relevant nodes

The $P$. lumaireul, $P$. csikii and $P$. septimaniae lineages revealed contrasting distributions. In the four lowland streams, only endemic $P$. lumaireul were found, except a single individual recognised as $P$. csikii in the Varaita stream (VAR; Table 1). In the Alpine lakes, however, different Phoxinus cryptic species were detected (Table 2): all three Phoxinus species were present together in two lakes only (ARP and MAD), endemic P. lumaireul were allopatric in four lakes (VIA, AFF, RES and ORG), and sympatric with the aliens $P$. csikii or $P$. septimaniae in five and 
Table 1 Genetic variability indices for each population of $P$. lumaireul within the lowland streams at the mitochondrial DNA (COI) and at the nuclear DNA (RAG1)

\begin{tabular}{|c|c|c|c|c|c|c|c|c|c|c|}
\hline \multirow[t]{2}{*}{ ID population } & \multicolumn{5}{|c|}{ COI mtDNA } & \multicolumn{5}{|c|}{ RAG1 nDNA } \\
\hline & $\mathrm{N}$ & $\mathrm{n}$ & $\mathrm{S}$ & $\mathrm{H}$ & $\pi(\%)$ & $\mathrm{N}$ & $\mathrm{n}$ & $\mathrm{S}$ & $\mathrm{H}$ & $\pi(\%)$ \\
\hline PEL & 22 & 6 & 5 & $0.53 \pm 0.12$ & $0.09 \pm 0.08$ & 18 & 2 & 2 & $0.21 \pm 0.11$ & $0.05 \pm 0.05$ \\
\hline $\mathrm{VAR}^{\mathrm{a}}$ & 22 & 4 & 3 & $0.64 \pm 0.06$ & $0.12 \pm 0.10$ & 46 & 8 & 9 & $0.32 \pm 0.09$ & $0.07 \pm 0.06$ \\
\hline PES & 17 & 1 & 0 & No variability & & 32 & 3 & 2 & $0.23 \pm 0.09$ & $0.03 \pm 0.03$ \\
\hline VAL & 21 & 3 & 2 & $0.34 \pm 0.12$ & $0.09 \pm 0.08$ & 34 & 7 & 8 & $0.42 \pm 0.10$ & $0.10 \pm 0.08$ \\
\hline Overall & 82 & 9 & 8 & $0.65 \pm 0.04$ & $0.18 \pm 0.12$ & 130 & 17 & 15 & $0.31 \pm 0.05$ & $0.07 \pm 0.06$ \\
\hline
\end{tabular}

$\mathrm{N}=$ number of individuals; $\mathrm{n}=$ number of haplotypes; $\mathrm{S}=$ number of polymorphic sites; $\mathrm{H}=$ haplotype diversity; and $\pi=$ nucleotide diversity. ID population code are explained in Online resources Table ESM 1

${ }^{\mathrm{a}}$ One individual clustered as $P$. csikii and was excluded from the genetic variability analysis

four lakes respectively (FIO, VIS, ROB, ANN and TER with $P$. csikii and CES, CHI, CAN and ISC with P. septimaniae; Table 2).

The mtDNA COI network analyses also detected the three Phoxinus species, highlighting three different structures (Fig. 3). The $14 \mathrm{mtDNA} P$. lumaireul haplotypes revealed a haplotype group with the most frequent haplotype (AP01) being central that was linked to three other frequent haplotypes by up to two mutational steps (AP02, AP05 and AP26) (Fig. 3). The remaining 10 haplotypes were shared by only a small number of individuals (one to three) and were linked to AP01 by one to three mutational steps (Fig. 3). AP01 and AP02 were more frequent in lowland streams, with lower frequencies in the Alpine lakes (Fig. 3; Table ESM 5). Conversely, AP05 and AP26 were more strongly represented in the Alpine lakes, with AP26 only found in these populations (Fig. 3; Table ESM 5). Of 10 P. septimaniae haplotypes, two were widespread (AP07 and AP53) and were connected by two mutational events, and six were single haplotypes that were separated from the two more frequent ones by between one and six mutational steps (Fig. 3). There were 16 unobserved haplotypes also detected (Fig. 3). P. csikii group comprised of only two haplotypes, with one widespread (AP03) and the other unique (AP77).

In $P$. lumaireul, there were similar levels of both haplotype $(\mathrm{H})$ and nucleotide genetic diversity indices $(\pi)$ between the two ecosystem types $(\mathrm{H}=0.65$ (stream) and 0.70 (lake); $\pi=0.18 \%$ (stream) and $0.23 \%$ (lake); Tables 1 and 2 respectively). For genetic diversity levels across the natural and introduced $P$. lumaireul populations, the highest levels of genetic diversity $(\mathrm{H}>0.60)$ were from one lowland stream population (VAR; Table 1) and four Alpine lakes (VIA, CES, CHI and ISC) (Table 2). There was no genetic variability in seven populations (one lowland stream (Table 1) and six Alpine lakes (Table 2)). In the alien minnows, genetic variability was the highest in $P$. septimaniae and the lowest in $P$. csikii (Table 2). In P. septimaniae, diversity indices were high $(\mathrm{H}>0.70 ; \pi>0.40 \%)$ in all those populations with more than one specimen present, except for two populations (ARP and ISC; Table 2). In $P$. csikii, genetic variability was only evident in two out of nine populations (Table 2).

\section{Nuclear DNA variability and MSN}

There were 44 haplotypes identified in the 852 bplength multiple alignment of the 194 RAG1 alleles that were obtained by phasing the 65 nDNA sequences produced in this study and the 32 sequences retrieved from GenBank (Online resources Table ESM 5); 45 polymorphic sites were detected of which 12 were singletons and 33 were parsimony informative sites. Thirty-three single nucleotide polymorphisms were detected, whilst no insertions or deletions were observed. Of the 44 haplotypes, 17 haplotypes were detected between the sequences produced in this study and of these, two (Hap2 and Hap16) were already present in GenBank (Fig. 4; Table ESM 6). They corresponded to $P$. lumaireul haplotypes (accession $\mathrm{N}^{\circ}$ MF408060 and MF408066, respectively; Palandačić et al. 2017). Indices of genetic variability ranged 


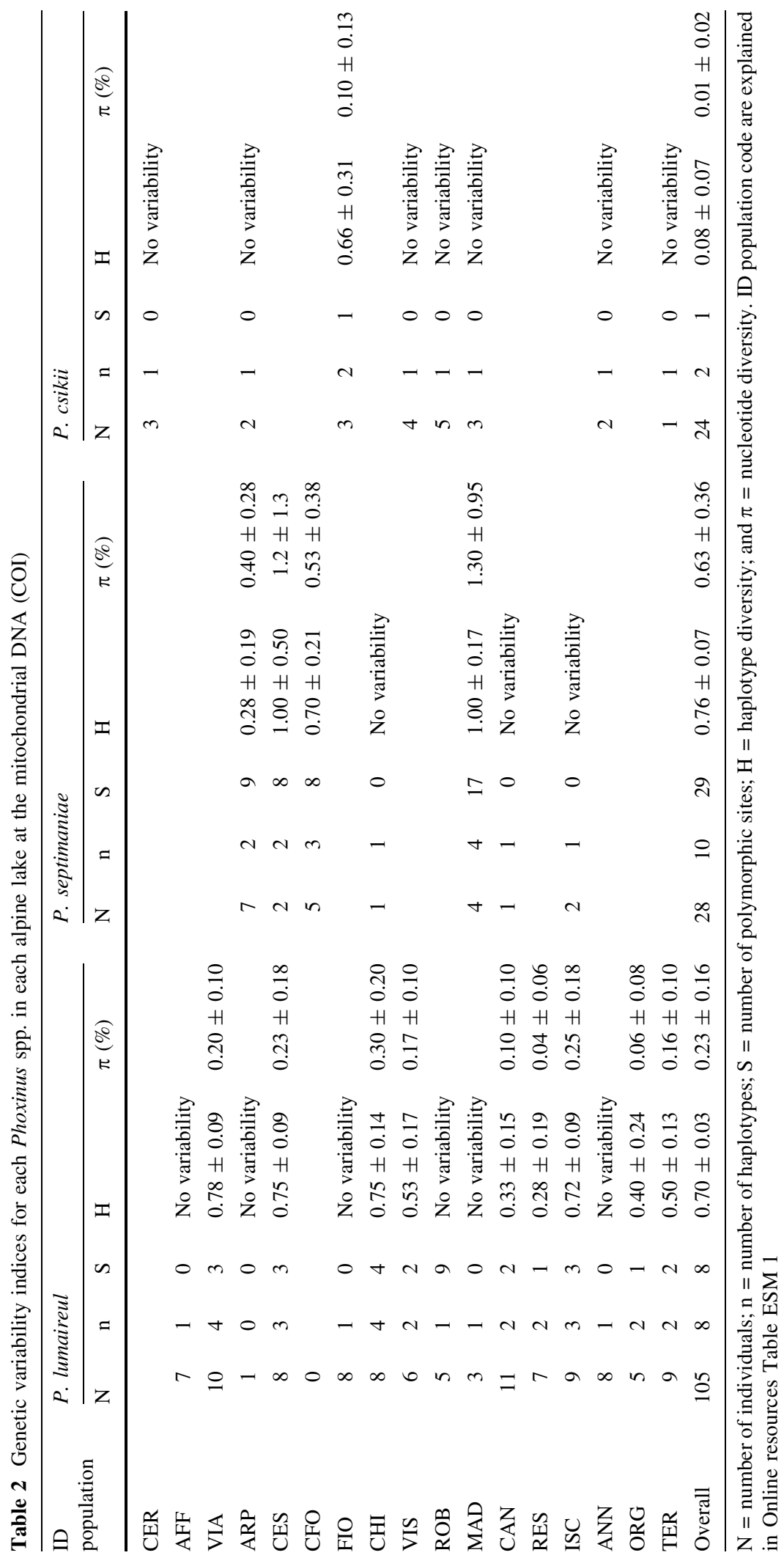




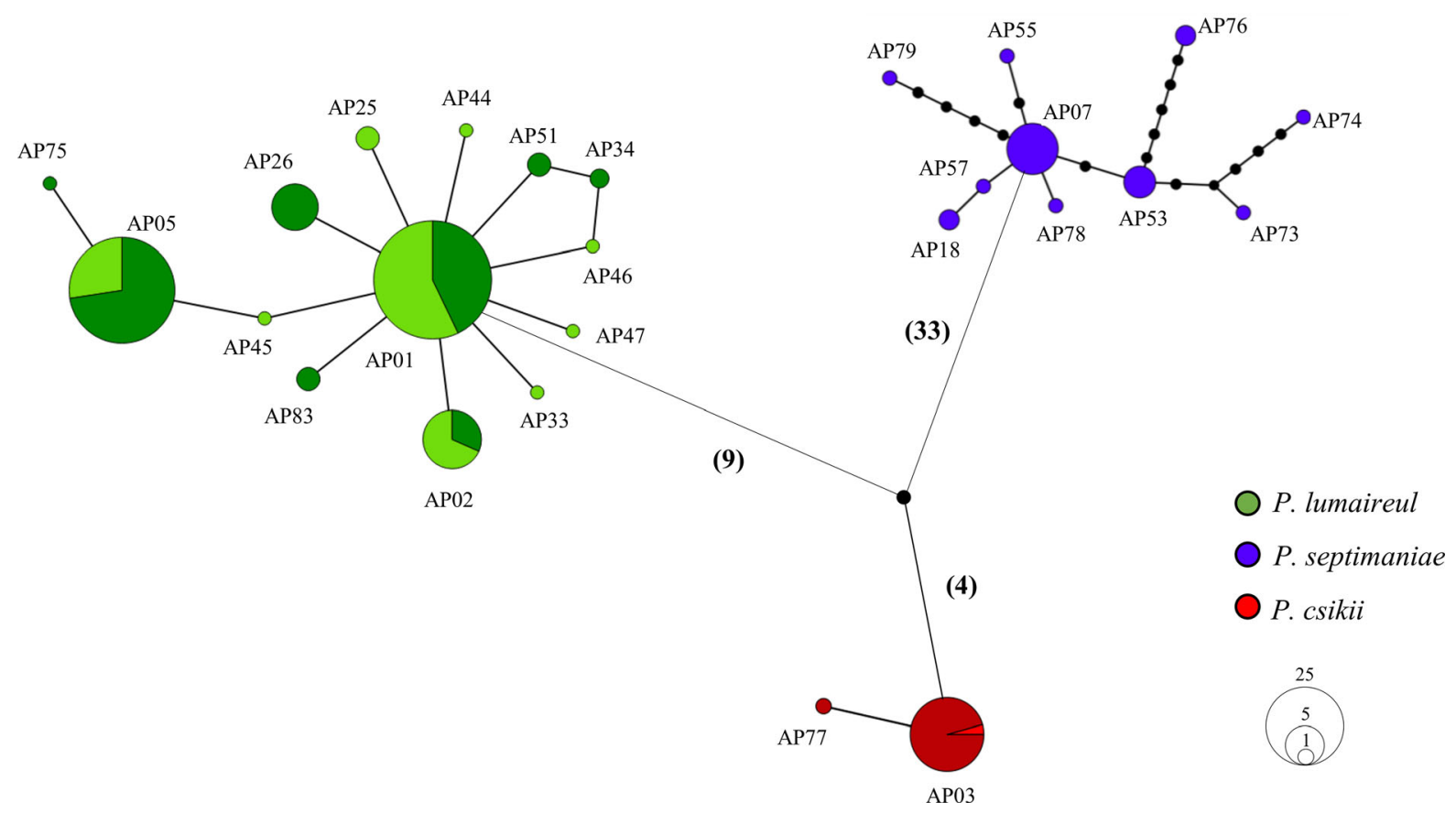

Fig. 3 COI mtDNA haplotype network obtained on the 239 Phoxinus spp. sequences detected between the four lowland streams and the 17 Alpine lakes. Circle size is proportional to the observed haplotype frequencies and black points represent unobserved haplotypes and potential intermediates. Mutational

between 0.21 and $0.42(\mathrm{H})$, and between $0.03 \%$ and $0.10 \%(\pi)$. PEL and PES populations were the least variable, whilst VAR was the most variable (Table 1).

The network analysis revealed a complex structure in which haplotypes of different mitochondrial lineages did not form a group but were instead spread with varied interconnections. Many of the sequences obtained in the study grouped within the most frequent haplotype (Hap2) that was shared only by P. lumaireul specimens (Fig. 4; Table ESM6). Three haplotypes were separated by four (Hap6) and five (Hap7 and Hap9) mutation steps from Hap2, a high number that may be representative of a different species, although the weak correspondence between RAG1 haplotypes and mitochondrial lineages prevented further interpretation of this result.

\section{Discussion}

The results revealed, for the first time, the presence and co-existence of three European species of the Phoxinus genus in the westernmost part of the Po steps that separate the three minnow clades are instead reported as number between brackets. Colours highlight phylogenetic species attribution and colour hue indicate ecosystem type [lowland streams (light) and Alpine lakes (dark) (cf. Tables 1, 2)]

River basin of Italy: P. lumaireul, P. csikii and $P$. septimaniae. Whilst the three species have minimal morphological differences (Kottelat and Freyhof 2007), they formed independent and well-supported groups that were also in agreement with recent phylogenetic studies (Palandačić et al. 2017; CorralLou et al. 2019). P. lumaireul Schinz (1840) (subclade 1a sensu Palandačić et al. 2017) has been revalidated as an endemic to the north Adriatic basin (Kottelat and Freyhof 2007; Palandačić et al. 2017, 2020).

Phoxinus csikii (subclade 5a sensu Palandačić et al. 2017) was first described by Hankó 1922 from a karstic brook located in Montenegro and has been recently revalidated, based on both molecular (Palandačić et al. 2017) and morphological evidence (Ramler et al. 2016). Its natural distribution is the lower and middle part of the Danube River watershed of the Balkan Peninsula (Palandačić et al. 2020). P. septimaniae was originally described by Kottelat (2007) as native to the French Mediterranean basins (south-eastern France); it has been also detected in river basins in north-eastern Spain (Corral-Lou et al. 2019; Garcia-Raventós et al. 2020). Although its 

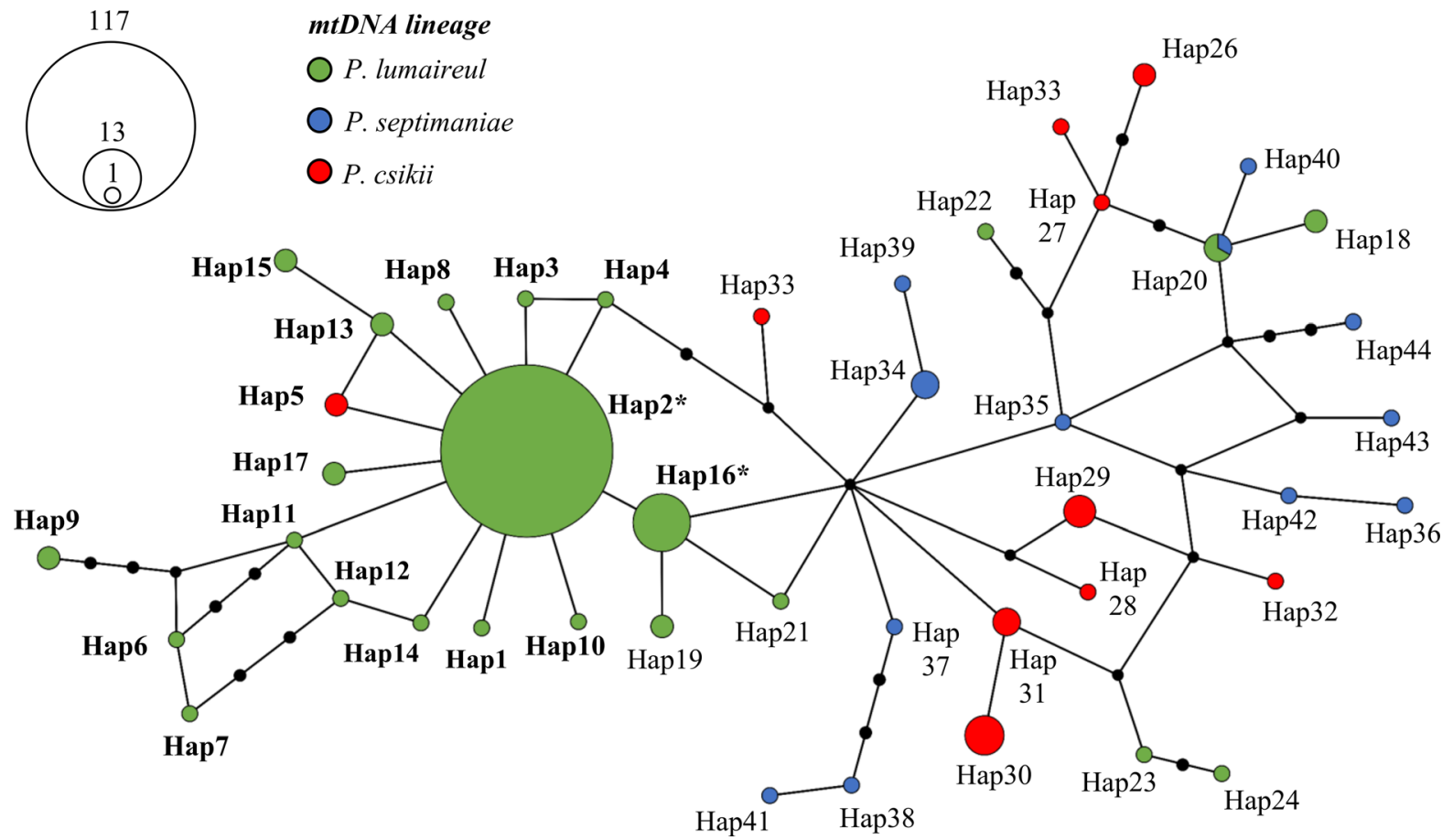

Fig. 4 RAG1 haplotype network of the 44 Phoxinus spp. haplotypes obtained from the 130 alleles produced in this study and the 64 alleles retrieved from GenBank (Online resource Table ESM 5). Circle size is proportional to the observed

natural or introduced origin could not be unambiguously discerned in this area of Spain, its geographic distribution resembles the Catalano-Provenzal endemics Squalius laietanus and Barbus meridionalis (Doadrio 2002) that do not naturally populate rivers of the north Adriatic basin. The endangered white clawed crayfish Austropotamobius pallipes occurs both in the Mediterranean French basins and Northern Italian basins, although its presence in the Italian Alps has been suggested as due to human translocations (Stefani et al. 2011). Here, the molecular results revealed $P$. septimaniae was not recorded in the lowland streams, corroborating that this species is not native to the western Po River basin.

A nuclear marker (RAG 1) was included in analyses, particularly for the lowland stream populations, in order to strengthen the results obtained from the mitochondrial DNA. The RAG 1 results revealed only a few of the least frequent haplotypes that were separated from the main haplotype by several mutational steps (four to five), could possibly belong to other species than the native $P$. lumaireul. The utility of RAG 1 marker was limited in depicting the haplotype frequencies and black points represent unobserved haplotypes and potential intermediates. Colours indicate mtDNA species attribution

phylogenetic relations between minnows that produced an uninformative network where well-defined mitochondrial lineages were not clear, as was evident in other studies (Corral-Lou et al. 2019; Palandačić et al. 2020). Although this could be due to the tendency of this species to hybridize (Corral-Lou et al. 2019), issues including incomplete lineage sorting and artefacts resulting from the gametic phasing or sequencing processes cannot be excluded from the evaluation of these results (Palandačić et al. 2020).

Despite the results from the nuclear DNA were unclear, the results of the mtDNA analyses revealed two important considerations on the distribution and community composition of minnows. Firstly, $P$. lumaireul was recorded from all sampled sites in the lowland rivers, where they were considered as natural, endemic populations. However, the presence of the exotic lineage $P$. csikii was detected in one stream, underlying a risk of a 'hidden invasion', even in these non-managed populations. Secondly, in the Alpine lakes, there is now a complex of cryptic Phoxinus species present that have resulted from unregulated introduction events. Although the introduction 
pathways of these minnows can only be speculated, it is likely that they occurred either unintentionally within contaminated batches of salmonid fishes being released into the lakes to enhance angling, or from their use as live-baits by anglers; both pathways are known sources of invasive minnows elsewhere in Europe (Museth et al. 2007; Miró and Ventura 2015). Patterns of fish introductions in high mountain lakes are often difficult to reconstruct due to a lack of associated information, although evidence suggests that in the Italian Alps at least, angling activities have been popular since the 1960s (Cantonati et al. 2006). The genetic structure and variability between the three cryptic species potentially provide valuable information about their introduction processes. Despite $P$. septimanae and $P$. csikii being recorded in a similar proportion of the lakes (eight and nine respectively), $P$. septimanae had the highest genetic variability, whereas $P$. csikii had a relatively simple genetic structure. $P$. lumaireul also showed a substantial gradient of genetic variability (negligible to high). Several studies have revealed invasive populations having much higher diversity than their native range due to local adaptation and/or admixture between different invasive lineages (Lawson Handley et al. 2011; Bock et al. 2015). Distinct genetic patterns observed for the three cryptic minnows here thus suggest multiple and/or older introductions for $P$. lumaireul and $P$. septimaniae, in contrast to a recent and/or single introduction event for $P$. csikii.

Although currently confined to the Alpine lakes, there is an inherent risk that the alien $P$. csikii and $P$. septimaniae could be unintentionally dispersed into streams in the Po basin by anthropogenic translocations (e.g. illegal stocking, Fernández et al. 2019), as has occurred in Germany (Knebelsberger et al. 2015), Austria and Croatia (Palandačić et al. 2020). If this happens, it is then probable that they would colonise streams where only endemic $P$. lumaireul is currently present. Given the phenotypic plasticity and morphological similarity of these minnows, there is then a threat that researchers and practitioners fail to detect their invasion unless genetic studies are completed, and this might only occur once the minnows have established and dispersed, a point when management options to conserve the native communities become inherently difficult (Britton et al. 2011). Indeed, identifying between native and introduced fishes in the field is a problem common to many invaded communities of cryptic cyprinid fishes, including between endemic and alien Barbus fishes in Italy (Zaccara et al. 2019), and native and alien Carassius in some European countries (Hänfling et al. 2005).

In conclusion, these results provide information on the composition of this cryptic complex of Phoxinus species and highlights a concerning conservation scenario for the lowland stream fish assemblages. The potential spread of these alien and cryptic minnows from highly managed ecosystems can contribute to the loss of integrity of freshwater communities that are already highly impacted by other stressors. The resolution of these issues thus requires on-going cooperation and collaboration between researchers, practitioners and regulators to ensure that introductions are prevented and, should this fail, then ensure the released fishes are rapidly identified, and then managed appropriately and according to their risk in the environment (Rytwinski et al. 2019).

Acknowledgements The authors wish to thank the fisheries departments for the local authorization of Hunting and Fishing Service of the Metropolitan City of Turin and by the Hunting, Fishing, Parks and Forestry Office of the Province of Cuneo to promote research activities in the field. We acknowledge Davide Bonetto and Paolo Lo Conte for their support in the field activities and the associated editors of Biological Invasions and anonymous reviewers that have suggested important revisions.

Funding Open access funding provided by Università degli Studi dell'Insubria within the CRUI-CARE Agreement. During field activities, the sampling protocols have been established in compliance with the ethical standards, ensuring that all necessary precautions have been taken and the welfare of the fish has been respected. This study was supported by grants from University of Insubria (Fondo di Ateneo per la Ricerca -FAR) to VDS and IV. Sampling activities were carried out thanks to scientific permits issued by the Hunting and Fishing Service of the Metropolitan City of Turin (Det. No 318 - 36321/2017) and by the Hunting, Fishing, Parks and Forestry Office of the Province of Cuneo $\left(\mathrm{N}^{\circ} 1590\right.$ dated 13/05/2016 and $\mathrm{N}^{\circ} 200$ dated $18 / 01 / 2018$ ). Genetic data produced in the study are available in GenBank public database under accession number specified in the text of the manuscript.

Open Access This article is licensed under a Creative Commons Attribution 4.0 International License, which permits use, sharing, adaptation, distribution and reproduction in any medium or format, as long as you give appropriate credit to the original author(s) and the source, provide a link to the Creative Commons licence, and indicate if changes were made. The images or other third party material in this article are included in the article's Creative Commons licence, unless indicated otherwise in a credit line to the material. If material is not included in the article's Creative Commons licence and your 
intended use is not permitted by statutory regulation or exceeds the permitted use, you will need to obtain permission directly from the copyright holder. To view a copy of this licence, visit http://creativecommons.org/licenses/by/4.0/.

\section{References}

Adams M, Raadik TA, Burridge CP, Georges A (2014) Global biodiversity assessment and hyper-cryptic species complexes: more than one species of elephant in the room? Syst Biol 63:518-533. https://doi.org/10.1093/sysbio/syu017

Aljanabi S, Martinez I (1997) Universal and rapid salt-extraction of high quality genomic DNA for PCR-based techniques. Nucleic Acids Res 25:4692-4693. https://doi.org/ 10.1093/nar/25.22.4692

Bazinet AL, Zwickl DJ, Cummings MP (2014) A gateway for phylogenetic analysis powered by grid computing featuring GARLI 2.0. Syst Biol 63:812-818

Bickford D, Lohman DJ, Sodhi NS, Ng PKL, Meier R, Winker K, Ingram KK, Das I (2007) Cryptic species as a window on diversity and conservation. Trends Ecol Evol 22:148-155. https://doi.org/10.1016/j.tree.2006.11.004

Bock DG, Caseys C, Cousens RD, Hahn MA, Heredia SM, Hübner S, Turner KG, Whitney KD, Rieseberg LH (2015) What we still don't know about invasion genetics. Mol Ecol 24:2277-2297. https://doi.org/10.1111/mec.13032

Britton JR, Gozlan RE, Copp GH (2011) Managing non-native fish in the environment. Fish Fish 12:256-274. https://doi. org/10.1111/j.1467-2979.2010.00390.x

Cantonati M, Lapini L, Paradisi S, Stoch F (2006) Conservation and management. In Stoch F (ed) High-altitude lakes. Quaderni habitat. Ministero dell'Ambiente e della Tutela del Territorio. Museo Friulano di Storia Naturale, pp 123-135

Corral-Lou A, Perea S, Aparicio E, Doadrio I (2019) Phylogeography and species delineation of the genus Phoxinus Rafinesque, 1820 (Actinopterygii: Leuciscidae) in the Iberian Peninsula. J Zool Syst Evol Res 57:926-941. https://doi.org/10.1111/jzs.12320

Doadrio I (2002) Atlas y libro rojo de los peces continentales de Espana; Ambiente MdM, editor. Madrid, Spain

Eschmeyer WN, Fricke R, Van Der Laan R (2020) Catalog of fishes: genera, species, references. http://researcharchive. calacademy.org/research/ichthyology/catalog/fishcatmain. asp. Accessed 9 Aug 2020

Fernández S, Arboleya E, Dopico E, Ardura A, García-Vázquez E (2019) Non-indigenous fish in protected spaces: trends in species distribution mediated by illegal stocking. Aquat Conserv Mar Freshw Ecosyst. https://doi.org/10.1002/aqc. 3238

Gallardo B, Clavero M, Sánchez MI, Vilà M (2016) Global ecological impacts of invasive species in aquatic ecosystems. Glob Chang Biol 22:151-163. https://doi.org/10. 1111/gcb.13004

Garcia-Raventós A, Martins FMS, Teixeira A, Sousa R, Froufe E, Varanda S, Lopes-Lima M, Beja P, Filipe AF (2020) Origin and history of Phoxinus (Cyprinidae) introductions in the Douro Basin (Iberian Peninsula): an update inferred from genetic data. Biol Invasions 22:2409-2419. https:// doi.org/10.1007/s10530-020-02279-5

Giussani G (1997) Appunti sulla fauna ittica d'acqua dolce. Consiglio nazionale delle ricerche, Istituto italiano di idrobiologia CNR Pallanza, 174 pp (in Italian)

Hänfling B, Bolton P, Harley M, Carvalho GR (2005) A molecular approach to detect hybridisation between crucian carp (Carassius carassius) and non-indigenous carp species (Carassius spp. and Cyprinus carpio). Freshw Biol 50:403-417. https://doi.org/10.1111/j.1365-2427.2004. 01330.x

Hankó BH (1922) A Magyar Tudományos Akadémia BalkánKutatásainak tudományos eredményei, vol 1, pp 1-6 (in Hungarian and German)

Hermoso V, Clavero M, Blanco-Garrido F, Prenda J (2011) Invasive species and habitat degradation in Iberian streams: an analysis of their role in freshwater fish diversity loss. Ecol Appl 21:175-188. https://doi.org/10.1890/092011.1

Jersabek CD, Brancelj A, Stoch F, Schabetsberger R (2001) Distribution and ecology of copepods in mountainous regions of the Eastern Alps. Hydrobiologia 453:309-324. https://doi.org/10.1023/A:1013113327674

Knebelsberger T, Dunz AR, Neumann D, Geiger MF (2015) Molecular diversity of Germany's freshwater fishes and lampreys assessed by DNA barcoding. Mol Ecol Resour 15:562-572. https://doi.org/10.1111/1755-0998.12322

Kottelat M (2007) Three new species of Phoxinus from Greece and southern France (Teleostei: Cyprinidae). Ichthyol Explor Freshw 18:145-162

Kottelat M, Freyhof J (2007) Handbook of European freshwater fish. Kottelat, Cornol

Lanzoni M, Milardi M, Aschonitis V, Fano EA, Castaldelli G (2018) A regional fish inventory of inland waters in Northern Italy reveals the presence of fully exotic fish communities. Eur Zool J 85:1-7. https://doi.org/10.1080/ 24750263.2017.1415384

Lawson Handley LJ, Estoup A, Evans DM, Thomas CE, Lombaert E, Facon B, Aebi A, Roy HE (2011) Ecological genetics of invasive alien species. Biocontrol 56:409-428. https://doi.org/10.1007/s10526-011-9386-2

Leigh JW, Bryant D (2015) PopArt: full-feature software for haplotype network construction. Methods Ecol Evol 6:1110-1116. https://doi.org/10.1111/2041-210x.12410

Leprieur F, Beauchard O, Blanchet S, Oberdorff T, Brosse S (2008) Fish invasions in the world's river systems: when natural processes are blurred by human activities. PLoS Biol 6:e28. https://doi.org/10.1371/journal.pbio.0060028

Mayden RL, Chen WJ (2010) The world's smallest vertebrate species of the genus Paedocypris: a new family of freshwater fishes and the sister group to the world's most diverse clade of freshwater fishes (Teleostei: Cypriniformes). Mol Phylogenet Evol 57:152-175. https://doi.org/10.1016/j. ympev.2010.04.008

Milardi M, Aschonitis V, Gavioli A, Lanzoni M, Fano EA, Castaldelli G (2018) Run to the hills: exotic fish invasions and water quality degradation drive native fish to higher altitudes. Sci Total Environ 624:1325-1335. https://doi. org/10.1016/j.scitotenv.2017.12.237

Miró A, Ventura M (2015) Evidence of exotic trout mediated minnow invasion in Pyrenean high mountain lakes. Biol 
Invasions 17:791-803. https://doi.org/10.1007/s10530014-0769-z

Morais P, Reichard M (2018) Cryptic invasions: a review. Sci Total Environ 613:1438-1448. https://doi.org/10.1016/j. scitotenv.2017.06.133

Museth J, Hesthagen T, Sandlund OT, Thorstad EB, Ugedal O (2007) The history of the minnow Phoxinus phoxinus (L.) in Norway: from harmless species to pest. J Fish Biol 71:184-195. https://doi.org/10.1111/j.1095-8649.2007. 01673.x

Nocita A, Tricarico E, Bertolino S (2017) Fine-scale analysis of heavily invaded Italian freshwater fish assemblages. Integr Zool 12:500-511

Palandačić A, Naseka A, Ramler D, Ahnelt H (2017) Contrasting morphology with molecular data: an approach to revision of species complexes based on the example of European Phoxinus (Cyprinidae). BMC Evol Biol 17:184. https://doi.org/10.1186/s12862-017-1032-x

Palandačić A, Kruckenhauser L, Ahnelt H, Mikschi E (2020) European minnows through time: museum collections aid genetic assessment of species introductions in freshwater fishes (Cyprinidae: Phoxinus species complex). Heredity. https://doi.org/10.1038/s41437-019-0292-1

Pfenninger M, Schwenk K (2007) Cryptic animal species are homogeneously distributed among taxa and biogeographical regions. BMC Evol Biol 7:121. https://doi.org/10. 1186/1471-2148-7-121

Ramler D, Palandačić A, Delmastro GB, Wanzenböck J, Ahnelt H (2016) Morphological divergence of lake and stream Phoxinus of Northern Italy and the Danube basin based on geometric morphometric analysis. Ecol Evol 7:572-584. https://doi.org/10.1002/ece3.2648

Ronquist F, Teslenko M, Van Der Mark P, Ayres DL, Darling A, Höhna S, Larget B, Liu L, Suchard MA, Huelsenbeck JP (2012) MrBayes 3.2: efficient Bayesian phylogenetic inference and model choice across a large model space. Syst Biol 61:539-542. https://doi.org/10.1093/sysbio/ sys029

Rozas J, Ferrer-Mata A, Sánchez-DelBarrio JC, Guirao-Rico S, Librado P, Ramos-Onsins SE, Sánchez-Gracia A (2017) DnaSP 6: DNA sequence polymorphism analysis of large data sets. Mol Biol Evol 34:3299-3302. https://doi.org/10. 1093/molbev/msx248
Rytwinski T, Taylor JJ, Donaldson LA, Britton JR, Browne DR, Gresswell RE, Lintermans M, Prior KA, Pellatt MG, Vis C, Cooke SJ (2019) The effectiveness of non-native fish removal techniques in freshwater ecosystems: a systematic review. Environ Rev 27:71-94. https://doi.org/10.1139/er2018-0049

Smith KF, Thia J, Gemmill CEC, Craig CS, Fidler AE (2012) Barcoding of the cytochrome oxidase I (COI) indicates a recent introduction of Ciona savignyi into New Zealand and provides a rapid method for Ciona species discrimination. Aquat Invasions 7:305-313. https://doi.org/10. 3391/ai.2012.7.3.002

Stefani F, Zaccara S, Delmastro GB, Buscarino M (2011) The endangered white-clawed crayfish Austropotamobius pallipes (Decapoda, Astacidae) east and west of the Maritime Alps: a result of human translocation? Conserv Genet 12:51-60. https://doi.org/10.1007/s10592-009-9986-x

Swofford DL (2002) PAUP*_phylogenetic analysis using parsimony, version 40b10. Sinauer Associates Inc., Sunderland

Tiberti R, von Hardenberg A, Bogliani G (2014) Ecological impact of introduced fish in high altitude lakes: a case of study from the European Alps. Hydrobiologia 724:1-19. https://doi.org/10.1007/s10750-013-1696-1

Uchii K, Doi H, Minamoto T (2016) A novel environmental DNA approach to quantify the cryptic invasion of nonnative genotypes. Mol Ecol Resour 16:415-422. https:// doi.org/10.1111/1755-0998.12460

Vander Zanden MJ, Hansen GJ, Higgins SN, Kornis MS (2010) A pound of prevention, plus a pound of cure: early detection and eradication of invasive species in the Laurentian Great Lakes. J Great Lakes Res 36:199-205. https://doi. org/10.1016/j.jglr.2009.11.002

Zaccara S, Quadroni S, Vanetti I, Carosi A, La Porta G, Crosa G, Britton JR, Lorenzoni M (2019) Morphologic and genetic variability in the Barbus fishes (Teleostei, Cyprinidae) of Central Italy. Zool Scr 48:289-301. https://doi.org/10. 1111/zsc. 12341

Publisher's Note Springer Nature remains neutral with regard to jurisdictional claims in published maps and institutional affiliations. 